\title{
Economics of Weed Management Methods as Influenced by Row-Spacing in Cowpea
}

\author{
O. Adewale Osipitan ${ }^{1}$, I. Yahaya ${ }^{2} \&$ Joseph A. Adigun ${ }^{3}$ \\ ${ }^{1}$ Northeast Research and Extension Center, University of Nebraska-Lincoln, USA \\ ${ }^{2}$ Council for Scientific and Industrial Research, Savanna Agricultural Research Institute, Ghana \\ ${ }^{3}$ Federal University of Agriculture, Abeokuta, Nigeria \\ Correspondence: O. Adewale Osipitan, Northeast Research and Extension Center, University of \\ Nebraska-Lincoln, 57905866 Road, Concord, NE 68728-2828, USA. E-mail: waleos08@yahoo.com
}

Received: November 12, 2017

Accepted: December 20, 2017 Online Published: January 15, 2018

doi:10.5539/jas.v10n2p98

URL: https://doi.org/10.5539/jas.v10n2p98

\begin{abstract}
Weed management is an important factor that influences the economic importance of cowpea as a cheap source of food and income for many farmers. A study was conducted to evaluate economic benefits of weed management methods used singly or in an integrated approach, and to understand the influence of row-spacing on economic benefits of weed management methods. Total variable cost of cowpea cultivation was substantially influenced by cost of weed control. A single input of hand weeding resulted in higher cost of weed control than a single input of PRE-herbicide for weed control. Increase in weed control inputs or frequency did not guarantee an increase in economic benefits. For example, removing weeds three times with hand at 3,6 and 9 weeks after planting (WAP) during the cowpea growing season did not necessarily result in the highest yield, but rather increased the variable cost of weed control. Integrating PRE-herbicide and hand weeding for weed management resulted in the highest yield and gross profit. The lowest cost of weed control provided by using PRE-herbicide gave the highest benefit-cost ratio. The differences in economic values of weed management methods were mostly not affected by cowpea row-spacing, but generally, economic benefits of management methods decreased with increase in row-spacing. Practically, this study suggests that minimizing the use of hand weeding by complementing with PRE-herbicide for weed management could help to optimize yield, and increase profitability, particularly under a narrow row-spacing in cowpea cultivation.
\end{abstract}

Keywords: economics, cowpea, weed management

\section{Introduction}

An integrated weed management (IWM) approach combines two or more weed control methods, which are likely to prove more effective than any single method in alleviating the build-up of weeds in a crop (Lamichhane et al., 2017). IWM provides diverse weed control tools that are feasible in a given socio-economic situation and implies them in a very precise manner both spatially and temporally. Hand weeding is the conventional method of weed control in cowpea in many parts of Africa (Osipitan, 2017). This weed control method is expensive, and labour is not usually available during the growing season due to workload (Lagoke et al., 1982). The frequency of weed removal using the conventional method determines cowpea yield and farmers are often unaware of its importance (Adigun et al., 2014). The use of herbicides in cowpea to control weeds appears to be useful (Dadari, 2003; Silva, 2003), but are rarely used. Cowpea is more sensitive to herbicides than most of the other grain legumes crops, and there are limited herbicide options available that can provide a broad and long-lasting weed control throughout the cowpea growing season (Yadav et al., 2017). One of the widely studied cultural methods that can potentially supplement other weed control tools in weed suppression and increase cowpea yield is row-spacing (or seeding rate). Cowpea planted with narrow spacing generally has quicker ground cover that provides shades for weed suppression (Adigun et al., 2014). Hence, integrating these components of weed control could help to effectively manage weeds and reduce or, prevent yield loss in cowpea.

A number of factors limit the economic importance of cowpea (Vigna unguiculata L. Walp) as a cheap source of food and income to many farmers, and an important limiting factor is weed management (Lagoke \& Shebayan, 1988). Weeds alone could cause 25 to $69 \%$ yield loss in cowpea (Adigun et al., 2014). There is an increasing 
suggestion for adoption of IWM approaches in crop production systems, as these approaches are usually effective, sustainable, and in some cases economical in managing weeds.

Studies have been conducted to evaluate weed management practices including IWM with the best agronomic yield in cowpea (Osipitan et al., 2013, 2016; Adigun et al., 2014), however, reports have shown that a management practice with best agronomic yield may not necessarily translate to best economic benefit to farmers (Gupta et al., 2016; Sepat et al., 2017). Therefore, the objectives of this study were to evaluate: (1) economic benefits of weed management methods used singly and in an integrated approach; (2) influence of row-spacing on economic benefits of weed management methods.

\section{Materials and Methods}

\subsection{Field Study}

Field trials were conducted during the early and late wet seasons of 2009 at the Federal University of Agriculture, Abeokuta $\left(7^{\circ} 20^{\prime} \mathrm{N}, 3^{\circ} 23^{\prime} \mathrm{E}\right)$ in South Western Nigeria. The study was conducted in a split-plot design with weed management method as the main plot and row-spacing as the sub-plot treatment in three replications.

\subsection{Treatments}

The plot treatments for weed management methods were:

(1) Pre-emergence (PRE) application of Codal ${ }^{\circledR}$ (S-metolachlor, 16\% w/w + Prometryn, $25 \% \mathrm{w} / \mathrm{w}$ ) at $2.4 \mathrm{~L} / \mathrm{ha}$ (T1); (2) PRE application of Codal ${ }^{\circledR}$ at $4.8 \mathrm{~L} / \mathrm{ha} \mathrm{(T2);} \mathrm{(3)} \mathrm{PRE} \mathrm{application} \mathrm{of} \mathrm{Codal}{ }^{\circledR}$ at $2.4 \mathrm{~L} /$ ha followed by (fb) hand weeding/ha at 6 weeks after planting (WAP) (T3); (4) One hand weeding/ha at 3 WAP (T4); (5) Two hand weeding/ha at 3 and 6 WAP (T5); (6) Three hand weeding/ha at 3, 6 and 9 WAP (T6); (7) Unweeded control (T7).

The sub-plot treatments were row-spacing at 60,75 and $90 \mathrm{~cm}$, which were equivalent to 20,16 and $11 \mathrm{~kg} \mathrm{ha}^{-1}$ seeding rates, respectively.

\subsection{Cowpea Variety, Planting and Management}

The cowpea variety used was Ife Bimpe from Institute of Agricultural Research and Training, Nigeria. The seeds were medium sized, light brown in color, medium maturing ( 75 days), semierect and determinate. The land was ploughed and disk harrowed at two-week interval. Cowpea seeds were sown by hand as soon as the rain established in both early and late wet seasons. Fertilizers at the rate of $45 \mathrm{~kg} \mathrm{ha}^{-1}$ each of $\mathrm{P}_{2} \mathrm{O}_{5}$ and $\mathrm{K}_{2} \mathrm{O}$ were broadcasted before harrowing. The plot sizes were $(3 \times 4.5) \mathrm{m}^{2}$ and $(1.5 \times 3.0) \mathrm{m}^{2}$ respectively. PRE-emergence application of herbicide $\left(\mathrm{Codal}^{\circledR}\right)$ was done with knapsack (CP3) sprayer calibrated to deliver a volume of $200 \mathrm{~L}$ $\mathrm{ha}^{-1}$ using a green deflector nozzle at a pressure of $2 \mathrm{~kg} \mathrm{~cm}^{-2}$.

\subsection{Harvesting}

Cowpea pods from each net plot were harvested by hand as soon as the pods dried but before shattering. The harvested pods were sun dried for 4 days, and then threshed. Grains from the threshed pods of each plot were weighed, and yields were expressed on per hectare basis.

\subsection{Economic Data}

The collected economic data were based on either direct or indirect cost during the study. The direct cost were those incurred for each treatments during the study such as cost of seeds, herbicides, and planting. While the indirect cost were those not paid for during the study, but would ideally be paid for by a farmer on per hectare farming, and these includes cost of herbicide application, and hand weeding.

\subsection{Economic Analysis}

In this study, the concept of economic analysis of weed management methods and row-spacing in cowpea was based on gross profit analysis using partial budgeting.

\subsubsection{Total Variable Cost (TVC) of Cultivation (\$/ha)}

Cost of cultivation was calculated based on cost of seeds, planting, and weed control. Others costs, such as tillage and harvesting cost were not included in the analysis, as they were constant and adding them resulted to negative economic values.

\subsubsection{Total Revenue (TR) (\$/ha)}

Harvested grain yields were converted to total revenue (\$/ha) based on existing market price. The formula used in calculating the revenue is shown below: 


$$
\text { TR }=\text { Quantity } \times \text { Price }
$$

Where, TR was total revenue per hectare (\$/ha), Quantity was total cowpea grain yield harvested in kilograms per hectare $(\mathrm{kg} / \mathrm{ha})$, Price was the market price of cowpea $(\$ / \mathrm{kg})$.

\subsubsection{Gross Profit (GP) (\$/ha)}

Gross profit for each weed management method and/or row-spacing was calculated by deducting the total cost of cultivation from the return. The following formula was used to calculate the gross profit per hectare:

$$
G P=T R-T V C
$$

Where, GP was the gross profit per hectare (\$/ha), $T R$ was the total revenue per hectare (\$/ha) and was calculated as shown in Equation 1, TVC is the total variable cost of cultivation ( $\$ /$ ha). This was calculated using the cost of planting, labor cost of weed control by hand weeding and by PRE-herbicide, and costs of PRE-herbicide as well as the cost of seeds.

\subsubsection{Benefit-Cost Ratio}

Benefit-cost ratio for each treatment was calculated by dividing gross profit by total cost of cultivation. The benefit cost ratio was calculated using the following formula:

$$
B C_{\text {ratio }}=\frac{G P}{T V C}
$$

Where, $B C_{\text {ratio }}$ was the benefit-cost ratio, GP and $T V C$ were as defined above.

\section{Results and Discussion}

\subsection{Cost, Grain Yield, Profitability and Benefit-Cost Ratio of Weed Management Methods}

The impact of weed management method on total variable cost of cultivation, grain yield, gross profit, and benefit-cost ratio of cowpea is shown in Table 1. Total variable costs of cultivation were higher in all weed management methods than unweeded control and differences were mainly due to cost of weed control. Removing weeds thrice by hand, at 3, 6, and 9 WAP (T6) incurred the highest total cost (\$132/ha) compared to other weed management methods due to accumulated labour cost as suggested by cost of weed control. On per unit input, the use of PRE-herbicide (T1) as a single input of weed control incurred less cost compared to hand weeding (T4) as a single input. The relatively higher cost incurred by hand weeding could be attributed to increase in required labour, which were usually expensive. This finding confirmed other reports that, the use of herbicide for weed control is less expensive than hand weeding (Oerke, 2006; Patil et al., 2014).

Table 1. Economic values of weed management methods for cowpea cultivation averaged for two trials

\begin{tabular}{llllllll}
\hline \multirow{2}{*}{ Variable } & \multicolumn{7}{c}{ Weed management } \\
\cline { 2 - 7 } & T1 & T2 & T3 & T4 & T5 & T6 & T7 \\
\hline Costs $(\$ /$ ha) & 7.4 & 7.4 & 7.4 & 7.4 & 7.4 & 7.4 & 7.4 \\
Seed cost & 64.7 & 64.7 & 64.7 & 64.7 & 64.7 & 64.7 & 64.7 \\
Planting cost & 10.9 & 21.8 & 38.9 & 20 & 40 & 60 & 0.0 \\
Weed control cost & 83 & 93.9 & 111 & 92.1 & 112.1 & 132.1 & 72.1 \\
Total cost & & & & & & & \\
Returns & 481.4 & 430.2 & 562 & 406.9 & 539.6 & 558 & 267.9 \\
Yield (kg/ha) & 226.2 & 202.2 & 264 & 191.3 & 253.6 & 262.3 & 125.9 \\
Total revenue $(\$ /$ ha) & 143.4 & 108.3 & 154 & 99.3 & 141.6 & 130.2 & 53.8 \\
Gross profit $(\$ /$ ha) & 1.73 & 1.12 & 1.40 & 1.07 & 1.26 & 0.98 & 0.76 \\
Benefit-cost ratio & & & & & & & \\
\hline
\end{tabular}


Table 2. Breakdown of economic values of weed management methods for cowpea cultivation under three row-spacing averaged for two trials

\begin{tabular}{|c|c|c|c|c|c|c|c|c|c|}
\hline \multirow{2}{*}{$\begin{array}{l}\text { Row spacing } \\
(\mathrm{cm})\end{array}$} & \multirow{2}{*}{$\begin{array}{l}\text { Weed } \\
\text { management }\end{array}$} & \multicolumn{4}{|c|}{ Costs $(\$ / \mathrm{ha})$} & \multicolumn{3}{|c|}{ Returns } & \multirow{2}{*}{$\begin{array}{l}\text { Benefit-cost } \\
\text { ratio }\end{array}$} \\
\hline & & Seed & Planting & $\begin{array}{l}\text { Weed } \\
\text { control }\end{array}$ & Total & $\begin{array}{l}\text { Yield } \\
(\mathrm{kg} / \mathrm{ha})\end{array}$ & $\begin{array}{l}\text { Total revenue } \\
(\$ / h a)\end{array}$ & $\begin{array}{l}\text { Gross profit } \\
(\$ / \text { ha })\end{array}$ & \\
\hline \multirow[t]{8}{*}{60} & $\mathrm{~T} 1$ & 9.4 & 71.7 & 10.9 & 92 & 537.4 & 252.4 & 160.5 & 1.74 \\
\hline & $\mathrm{T} 2$ & 9.4 & 71.7 & 21.8 & 102.9 & 468.7 & 220 & 117.8 & 1.14 \\
\hline & $\mathrm{T} 3$ & 9.4 & 71.7 & 38.9 & 120 & 625.9 & 294.2 & 174.2 & 1.45 \\
\hline & $\mathrm{T} 4$ & 9.4 & 71.7 & 20 & 101.1 & 438 & 205.9 & 104.8 & 1.04 \\
\hline & $\mathrm{T} 5$ & 9.4 & 71.7 & 40 & 121.1 & 597.9 & 281 & 159.9 & 1.32 \\
\hline & T6 & 9.4 & 71.7 & 60 & 141.1 & 605.5 & 284.6 & 143.6 & 1.02 \\
\hline & $\mathrm{T} 7$ & 9.4 & 71.7 & 0 & 81.1 & 288.7 & 135.7 & 54.6 & 0.67 \\
\hline & \multicolumn{4}{|c|}{ Average for row-spacing } & 108.5 & 508.9 & 239.1 & 130.8 & 1.2 \\
\hline \multirow[t]{8}{*}{75} & $\mathrm{~T} 1$ & 7.5 & 66.5 & 10.9 & 84.9 & 485.2 & 228.2 & 143.3 & 1.69 \\
\hline & $\mathrm{T} 2$ & 7.5 & 66.5 & 21.9 & 95.9 & 428.7 & 201 & 105.1 & 1.10 \\
\hline & $\mathrm{T} 3$ & 7.5 & 66.5 & 38.9 & 112.9 & 556.1 & 261.4 & 148.5 & 1.32 \\
\hline & $\mathrm{T} 4$ & 7.5 & 66.5 & 20 & 94 & 405.5 & 190 & 96 & 1.02 \\
\hline & $\mathrm{T} 5$ & 7.5 & 66.5 & 40 & 114 & 539.2 & 253.4 & 139.4 & 1.22 \\
\hline & T6 & 7.5 & 66.5 & 60 & 134 & 554.1 & 260.4 & 126.5 & 0.94 \\
\hline & $\mathrm{T} 7$ & 7.5 & 66.5 & 0 & 74 & 271.7 & 127.7 & 53.7 & 0.73 \\
\hline & \multicolumn{4}{|c|}{ Average for row-spacing } & 101.4 & 462.9 & 217.4 & 116.1 & 1.1 \\
\hline \multirow[t]{8}{*}{90} & $\mathrm{~T} 1$ & 5.2 & 55.9 & 10.9 & 72 & 421.8 & 198.3 & 126.4 & 1.76 \\
\hline & $\mathrm{T} 2$ & 5.2 & 55.9 & 21.9 & 83 & 393.3 & 102 & 19.07 & 0.23 \\
\hline & $\mathrm{T} 3$ & 5.2 & 55.9 & 38.9 & 100 & 504.4 & 237.1 & 137.2 & 1.37 \\
\hline & $\mathrm{T} 4$ & 5.2 & 55.9 & 20 & 81.1 & 377.3 & 177.4 & 96.4 & 1.19 \\
\hline & $\mathrm{T} 5$ & 5.2 & 55.9 & 40 & 101.1 & 481.8 & 226 & 124.9 & 1.24 \\
\hline & T6 & 5.2 & 55.9 & 60 & 121.1 & 514.5 & 241.8 & 119.8 & 0.99 \\
\hline & $\mathrm{T} 7$ & 5.2 & 55.9 & 0 & 61.1 & 243.5 & 114.4 & 53.4 & 0.87 \\
\hline & \multicolumn{4}{|c|}{ Average for row-spacing } & 88.5 & 419.5 & 185.3 & 96.7 & 1.1 \\
\hline
\end{tabular}

Grain yields of all weed management methods were higher than the unweeded control. This was expected as it has been previously reported that allowing weeds to compete with cowpea could substantially reduce yield (Adigun et al., 2014; Gupta et al. 2016). The highest yield $(562 \mathrm{~kg} / \mathrm{ha}$ ) was obtained when weeds were removed with PRE-herbicide followed by hand weeding at 6 WAP (T3). The highest yield obtained could be attributed to early weed control by the PRE-herbicide and removal of later emerging weeds at the critical time by hand weeding (Dadari, 2003; Osipitan et al. 2016).

The results indicated that it was more profitable to control weeds in cowpea using any of the weed management methods than allowing weeds on the plots. This was clearly as a result of obtaining substantially higher yield in weed-controlled plots compared to unweeded plots. Integrating PRE-herbicide and hand weeding (T3) provided the highest gross profit (154\$/ha) due to increased yield at a relatively less cost. The findings is similar to that of Kumar and Singh (2017) in which integrated weed management treatments gave higher gross and net returns, compared to non-integrated approach. As suggested by the benefit-cost ratio, there was an increase in economic benefit for every $\$ 1$ spent on weed management except when weeds were frequently removed thrice by hand (T6) during the cowpea cultivation period. This was because increasing frequency of weed removal to three by hand did not guarantee highest yield (Adigun et al. 2014), but rather increased the cost of weed control. The highest benefit-cost ratio (1.73) was obtained with weed management using PRE-herbicide (2.4 L/ha) alone (T1), and this was largely due to relatively lower cost of weed control.

\subsection{Influence of Cowpea Row-Spacing on Cost, Grain Yield, Profitability and Benefit-Cost Ratio of Weed Management Methods}

The influence of cowpea row-spacing on cost, grain yield, gross profit and benefit-cost ratio of weed management methods is presented in Table 2. Reducing cowpea row-spacing increased cost of cultivation (88.5 to $108 \$ / \mathrm{ha}$ ), grain yield (419 to $508 \mathrm{~kg} / \mathrm{ha}$ ), gross profit (96.9 to $130.8 \$ / \mathrm{ha}$ ), and benefit-cost ratio (1.1 to 1.2$)$. 
Increase in cost of cultivation in the reduced row-spacing can be attributed to increase in required seeds per hectare with consequent increase in cost of seed and planting. The reduction in row-spacing increased total population of cowpea plant per hectare which subsequently increased grain yield. Reducing row-spacing also reduced the available space for weeds, thereby reducing the negative effect of weeds on cowpea yield (Osipitan et al., 2016). Removing weeds three times by hand (T6) during the cowpea growing season consistently incurred the highest cost of cultivation for all row-spacing. In all row-spacing, PRE application of herbicide at $2.4 \mathrm{~L} / \mathrm{ha}$ (T1) consistently resulted in the highest benefit-cost ratio, and when supplemented with hand weeding at 6 WAP (T3), the highest yield and gross profit were consistently obtained.

Generally, for all row-spacing, the order of benefit-cost ratio was $\mathrm{T} 1>\mathrm{T} 3>\mathrm{T} 5>\mathrm{T} 2>\mathrm{T} 4>\mathrm{T} 6>\mathrm{T} 7$ with one exemption. This exemption was found in $90 \mathrm{~cm}$ row-spacing, in which weed management with PRE-herbicide at a higher rate $(4.8 \mathrm{~L} / \mathrm{ha}, \mathrm{T} 2)$ resulted in benefit-cost ratio lower than the unweeded control. This could be attributed to relatively reduced yield as a result of cowpea injury caused by increased rate of the PRE-herbicide with associated reduction in plant population per hectare (Osipitan et al., 2013).

\section{Conclusion}

Total variable cost of cowpea cultivation was substantially influenced by cost of weed control. A single input of hand weeding resulted in higher cost of weed control than a single input of PRE-herbicide for weed control. Increase in weed control inputs or frequency did not guarantee increase in economic benefits. For example, removing weeds three times with hand at 3,6 and 9 WAP during cowpea growing season did not necessarily result in the maximum yield, but rather increased the cost of weed control. Integrating PRE-herbicide and hand weeding for weed management gave the highest yield and gross profit. The lowest cost of weed control provided by using PRE-herbicide gave the highest benefit-cost ratio. The differences in economic values of weed management methods were mostly not affected by cowpea row-spacing, but generally, economic benefits of management methods decreased with increase in row-spacing. Practically, this study suggests that minimizing the use of hand weeding by complementing with PRE-herbicide for weed management could help to optimize yield, and increase profitability and benefit-cost ratio; particularly under a narrow row-spacing in cowpea cultivation.

\section{References}

Adigun, J., Osipitan, A. O., Lagoke, S. T., Adeyemi, R. O., \& Afolami, S. O. (2014). Growth and yield performance of cowpea (Vigna unguiculata (L.) Walp) as influenced by row-spacing and period of weed interference in South-West Nigeria. Journal of Agricultural Science, 6(4), 188-198. https://doi.org/10.5539/ jas.v6n4p188

Dadari, S. A. (2003). Evaluation of herbicides in cotton/cowpea mixture in the Northern Guinea. Savannah. J. Sustainable Agric. Environ, 5, 153-9.

Gupta, K. C., Gupta, A. K., \& Rani, S. (2016). Weed management in cowpea [Vigna unguiculata (L.) Wasp.] under rainfed conditions. International Journal of Agricultural Sciences, 12(2), 238-240. https://doi.org/ 10.15740/HAS/IJAS/12.2/238-240

Kormawa, P. M., Chianu, J. N., \& Manyong, V. M. (2000). Cowpea demand and supply patterns in West Africa: The case of Nigeria. Proceedings of World Cowpea Conference III, September 4-7, 2000 (pp. 376-386). IITA, Ibadan, Nigeria.

Kumar, P., \& Singh, R. (2017). Influence of Weed Management Practices on Growth Parameters and Economics of Cowpea [Vigna unguiculata (L.) Wasp.]. Annual Research \& Review in Biology, 13, 1-9. https://doi.org/10.9734/ARRB/2017/33060

Lagoke, S. T. O., \& Shebayan, J. A. Y. (1988). Effectiveness and economics of chemical weed control in cowpea (Vigna unguiculata (L) Walp) in the Northern Guinea Savanna of Nigeria. Journal of Agricultural Research, 26(4), 333-342.

Lagoke, S. T. O., Chaudhary, A. H., \& Chandra-Singh, D. J. (1982). Chemical Weed Control in Rainfed Cowpea in the Guinea Savanna Zone of Nigeria. Weed Research, 22(1), 17-22. http://doi.org/10.1111/j.1365-3180.

Lamichhane, J. R., Devos, Y., Beckie, H. J., Owen, M. D., Tillie, P., Messéan, A., \& Kudsk, P. (2017). Integrated weed management systems with herbicide-tolerant crops in the European Union: Lessons learnt from home and abroad. Critical Reviews in Biotechnology, 37(4), 459-475. https://doi.org/10.1080/07388551.2016. 1180588 
Oerke, E. C. (2006). Crop losses to pests. The Journal of Agricultural Science, 144(1), 31-43. https://oi.org/ $10.1017 / \mathrm{S} 0021859605005708$

Osipitan, O. A. (2017). Weed Interference and Control in Cowpea Production: A Review. Journal of Agricultural Science, 9(12), 11-20. https://doi.org/10.5539/jas.v9n12p11

Osipitan, O. A., Adigun, J. A., \& Kolawole, R. O. (2016). Row spacing determines critical period of weed control in crop: Cowpea (Vigna unguiculata) as a case study. Azarian Journal of Agriculture, 3(5), 90-96.

Osipitan, O. A., Adigun, J. A., Lagoke, S. T. O., \& Afolami, S. O. (2013). Effect of inter-row spacing and weed control methods on growth and yield of cowpea (Vigna unguiculata L. Walp) in South Western Nigeria. Nigeria Journal of Plant Protection, 27, 97-111.

Patil, B. C., Padanad, L. A., Yashvantkumar, K. H., Soumya, S., \& Ravi, L. (2014). Efficacy and economics of integrated weed management in vegetable cowpea [Vigna unguiculata (L.) Walp]. Agriculture Update, 9(1), 124-127.

Sepat, S., Thierfelder, C., Sharma, A. R., Pavuluri, K., Kumar, D., Iquebal, M. A., \& Verma, A. (2017). Effects of weed control strategy on weed dynamics, soybean productivity and profitability under conservation agriculture in India. Field Crops Research, 210, 61-70. https://doi.org/10.1016/j.fcr.2017.05.017

Yadav, T., Nisha, K. C., Chopra, N. K., Yadav, M. R., Kumar, R., Rathore, D. K., \& Ram, H. (2017). Weed Management in Cowpea: A Review. Int. J. Curr. Microbiol. App. Sci., 6(2), 1373-1385. http://doi.org/10.20546/ijcmas.2017.602.156

\section{Copyrights}

Copyright for this article is retained by the author(s), with first publication rights granted to the journal.

This is an open-access article distributed under the terms and conditions of the Creative Commons Attribution license (http://creativecommons.org/licenses/by/4.0/). 